\title{
Agricultural utilisation and potential suitability of the Sysl'ovské polia Special Protection Area (south-western Slovakia) landscape in relation to the habitat requirements of the red-footed falcon (Falco vespertinus)
}

\author{
Využívanie pol'nohospodárskej krajiny a potenciálna vhodnost' Chráneného vtáčieho \\ územia Sysl'ovské polia (juhozápadné Slovensko) vo vzt'ahu k habitatovým nárokom sokola \\ kobcovitého (Falco vespertinus)
}

\author{
Martin ZEMKO, Peter PETLUŠ \& Viera PETLUŠOVÁ
}

\begin{abstract}
Intensification of land use in an agricultural landscape significantly affects biodiversity also in protected areas. This can be observed in the Sysl'ovské polia Special Protection Area in relation to the occurrence of the red-footed falcon (Falco vespertinus). The objective of this study was to evaluate the landscape structure and suitability of agrotechnical procedures for the habitat demands of this species in the course of the period from 2004 until 2017. The utilisation was assessed on the basis of four landscape elements representation in 1949 and 2017. The next step was analysis of landscape patches. The aim was to quantify the diversity and the spatial structure of the landscape mosaic using Shannon's Diversity Index and Evenness Index as well as Simpson's Diversity Index and Evenness Index and spatial pattern analysis in the Fragstats software programme. Assessment of crop suitability was carried out according to the following criteria: representation of positive/negative agricultural crops, diversity of crops in crop rotation, and (non-)observance of crop rotation. It was found that the agricultural landscape use did not change significantly. The study area has been used as an intensively-farmed agricultural landscape for a long time. The landscape elements have remained almost identical, with dominance of arable land. Differences emerged in the analysis of the micropatches, which are represented by natural hedgerows consisting of various species of trees, shrubs and grasses. The results show a decrease in the diversity of patches and changes in the structure of the landscape patches, which may be important in terms of the preservation of the habitat of fauna which form an important part of the $F$. vespertinus diet. On the basis of the evaluation of the suitability of agricultural crop growing, we found that there were some areas showing negative values in all the criteria, and thus they require changes in the crop rotation focusing on increasing positive crop diversity and the share of grassland.
\end{abstract}

\begin{abstract}
Abstrakt: Intenzifikácia pol’nohospodárskej krajiny výraznou mierou ovplyvňuje biodiverzitu častokrát aj v chránených územiach. Sledovat' to možno aj v Chránenom vtáčom území Sysl'ovské polia vo vzt'ahu k výskytu sokola kobcovitého (Falco vespetinus). Ciel'om bolo hodnotenie štruktúry krajiny a vhodnosti agrotechnických postupov pre habitatové nároky tohto druhu v časovom období rokov 2004 - 2017. Využívanie sa hodnotilo na základe zastúpenia štyroch krajinných prvkov v rokoch 1949 a 2017. Ďalším krokom bola analýza plôšok krajiny. Ciel’om bola kvantifikácia diverzity a priestorovej štruktúry krajinnej mozaiky s využitím Shannonovho indexu diverzity a vyrovnanosti a Simpsonovho indexu diverzity a vyrovnanosti v softvérovom prostredí Fragstats. Hodnotenie vhodnosti plodín sa realizovalo podl'a kritérií: zastúpenie pozitívnych/negatívnych pol’nohospodárskych plodín, diverzita plodín v osevnom postupe a dodržanie/nedodržanie osevného postupu. Zistilo sa, že využívanie pol’nohospodárskej krajiny sa výrazne nezmenilo. Územie sa dlhodobo využíva ako intenzívne využívaná pol'nohospodárska krajina. Zastúpenie krajinných prvkov bolo takmer totožné, prevažovala orná pôda. Rozdiely boli zistené pri analýze mikroplôšok, ktoré predstavujú napr. remízky s drevinami, krovinami a trávnatými porastmi. Hodnoty poukazujú na pokles diverzity plôšok a zmeny štruktúry plôšok krajiny, čo môže byt' významné z hl'adiska zachovania habitatov organizmov, ktoré sú dôležitou súčast'ou potravy $F$. vespertinus. Na základe hodnotenia vhodnosti pestovania pol'nohospodárskych plodín bolo zistené, že v území sa nachádzajú plochy, ktoré vykazovali negatívne hodnotenie vo všetkých kritériách, a preto si vyžadujú zmeny v osevnom postupe zamerané na zvýšenie diverzity tzv. pozitívnych plodín a zvýšenie podielu trvalých trávnych porastov.
\end{abstract}

Key words: landscape element, landscape structure, patch density, agricultural crops, crop diversity, crop rotation, technologies for crop farming

\footnotetext{
Martin Zemko, Peter Petluš, Viera Petlušová (corresponding author), Department of Ecology and Environmental Sciences, Faculty of Natural Sciences, Constantine the Philosopher University in Nitra, Tr. A. Hlinku 1, 94901 Nitra, Slovakia. E-mail: vpetlusova@ukf.sk.
}

Acknowledgement: Authors would like to thank to Ing. Pavel Sokol, CSc. for providing data on the crop rotation plans in the 
study area. The project results were obtained with the support of the LIFE11 NAT/HU/000926 Project - Conservation of the Redfooted Falcon in the Carpathian Basin and the UGA VIII/31/2017 Project - Impact of Alternative Land Use on the Red-footed Falcon.

\section{Introduction}

Agricultural landscape is the largest type of habitat within the EU countries, which more than half of endangered bird species living in Europe are to a large extent bound to (Krebs et al. 1999, Chamberlain et al. 2000, Donald et al. 2001, 2006, Robinson \& Sutherland 2002). On the other hand, the main task of agricultural landscape is the production of food, fuel and fibre (Godfray et al. 2010, UN DESA 2011). EU countries are the biggest producers of agricultural products and foodstuffs in the world (FAOSTAT 2007), which is reflected even in the current common agricultural policy of the EU member countries, where a particularly topical subject is environment quality, agricultural landscape condition and biodiversity (Bengtsson 2000). Agriculture significantly endangers biodiversity and it contributes to landscape homogenisation. Growing of monocultures (Flohre et al. 2011) reduces ecological stability, and increases the need for supplementary energy sources. It leads to decline in biological diversity caused mainly by fragmentation, loss of habitats and use of pesticides.

In the conditions of Slovakia the intensively cultivated agricultural landscape represents a refuge for the steppe species of animals which often find their marginal areas of distribution here. Slovakia, as an EU member country, is obliged to take care of the biodiversity of Europe and to provide favourable conditions for survival and protection to the species of European importance. The red-footed falcon (Falco vespertinus $\mathrm{L}$. 1766) is considered one of these species too and the NATURA 2000 areas in Slovakia have been declared for its protection. Its nesting habitats are the areas of open steppe and forest-steppe landscape (Slobodník et al. 2017) which in the conditions of southern Slovakia are represented by agrocenoses of the so-called cultural steppe. The landscape structure is formed by large-scale arable farms in these conditions. From the standpoint of food accessibility cultivation of cereals, alfalfa and grass crops and fallow with vegetation cover on arable land have positive impact. Trees (mostly Robinia pseudoacacia) in natural hedgerows cover $F$. vespertinus nesting demands.

According to Keve \& Szijj (1957) the red-footed falcon diet is composed mostly of insects (Orthoptera,
Odonota, Coleoptera), the presence of which indicates a balanced agricultural landscape. In suitable conditions small ground mammals linked to agrocenoses form a smaller part of the diet (Keve \& Szijj 1957, Haraszthy et al. 1994). We assume that the diet supply is strongly affected by the use of agrotechnical operations (such as alternation, diversity and suitability of the farmed crops), the structure of agricultural landscape and burdening of agrocenoses through the use of pesticides. The Sysl'ovské polia Special Protection Area is one of the protected bird areas in Slovakia in which $F$. vespertinus is the so-called criterion species. Nowadays (Slobodník et al. 2017) it represents the only known locality of its nesting in Slovakia.

The objective of this study was to assess and compare the landscape use structure (1949 vs. 2017) and suitability of agrotechnical operations in relation to the habitat demands of $F$. vespertinus in the period from 2004 until 2017. In the Pannonian Basin F. vespertinus prefers open landscape with sparse vegetation. For hunting it prefers short grass-herbaceous vegetation. In agrocenoses it prefers short crops with a shorter vegetation period which offer a dominant food supply. For nesting it uses non-forest, narrow, linear woody vegetation, which is part of the agricultural landscape like hedgerows, avenues or group of trees (Fülöp \& Szlivka 1988, Haraszthy et al. 1994, Purger 1996, 1997, Fehérvári et al. 2012).

\section{Material and methods}

The area with 1772.94 hectares is located in the Danubian Plain with a flat type of relief and the presence of plane depressions. The landscape is formed by agriculture which has dominant status in the area. Its formation and development is influenced by suitable natural conditions. The area is situated in a warm climatic region with hot and very dry climate. The soil types include fluvisols and chernozems (i.e. black soils), mostly heavy or medium, which are characterized by high production potential. Intensive agricultural activities pursued in large-scale fields in the protected area with the predominance of cultivated monocultures may have a negative impact on $F$. vespertinus and other important bird species.

In assessing the landscape we proceeded on the basis 
of two aspects: landscape use and suitability of arable crops with regard to the habitat demands of $F$. vespertinus.

\section{L a n d u s e}

Land use assessment was based on:

1. Quantitative presence of landscape elements in the landscape structure (each landscape element is represented by type of land use e.g. arable land, grass and herbaceous vegetation, road networks and other built-up areas). The aim was to express the process of land-use change (Ružička \& Ružičková 1973), e.g. transformation of grasslands into arable land.

2. Characteristics of landscape elements, especially diversity and spatial structure, whereby each landscape element can be expressed according to Forman \& Godron (1993) as a patch or a corridor, e.g. tree, shrub or grass hedgerow, or grass-herbaceous vegetation. In our assessment patches and corridors were evaluated together (uniformly named as patches). Their characteristics were assessed according to their shape, edge lengths, and number per area.

L a n d s c a e st r u c t r e a n a l y s i s The landscape structure was assessed and compared on the basis of the representation of the elements of landscape use in 1949 and 2017. Four groups of elements of landscape use were compiled for the analysis. On the basis of the representation of individual elements of landscape use pursuant to Ružička \& Ružičková (1973), analytical maps of the structure of landscape use for the periods of 1949 and 2017 were created by digitalising of orthophotomaps and their updating.

\section{L a n d s c a p e pat che s a n a lys is}

For the analysis we created raster maps with a raster of 1 metre. These were applied to analysis of the landscape patches (Forman \& Godron 1993, Forman 1995) using the Fragstats statistical software programme v 4.2.1 (McGarigal et al. 2012). The following characteristics of the landscape patches structure were studied: total edge (TE, in $\mathrm{m}$ ), edge density ( $\mathrm{ED}$, in $\mathrm{m} / \mathrm{ha}$ ), patch density (PD, in n/100 ha), using Shannon's Diversity Index and Evenness Index, and Simpson's Diversity Index, and Evenness Index. Hill (1973), Turner (1990), McGarigal and Marks (1995), Cushman et al. (2008) deal with these landscape characteristics in their works. These characteristics were observed within the whole area and compared for the periods of 1949 and 2017.
The analysis of patches was carried out in order to quantify the diversity and spatial structure of the landscape mosaic. We worked on the assumption (Forman \& Godron 1993) that the size, shape and evenness of landscape element distribution as well as the density of patches have an impact on the species diversity in the agricultural landscape. The influence of land use on biodiversity was also reported in Kalivoda et al. (2010). It was assumed that biodiversity was increased by the impact of edge effects with the growing length of patch borderlines and the patch density. At the same time we assumed that due to the presence of residual patches (e.g. remnants of small-scale farming, field paths, bosques, baulks) the heterogeneity of the landscape in the past (1949) was higher than today, even though the percentage representation of the individual elements of landscape use is now similar to the past.

\section{Suitability of arable crops for F. vespertinus}

In finding the suitable arable crops the crop rotation methods from the period between 2004 and 2017 were studied. We worked on the basis of the assumption by Palatitz et al. (2011) that the individual agricultural crops represented in the crop rotations may have, from the viewpoint of diet availability, positive or negative impact on the occurrence of $F$. vespertinus. Suitability of crop cultivation evaluation in the study area was adjusted to the agrotechnical requirements of the farming of agricultural crops in this maize production area (Holúbek et al. 2007, Černý \& Candráková 2015, Molnárová \& Žembery 2016). The suitability of crop cultivation evaluation was based on the development of the agricultural crops and agrotechnical procedures in the course of the year. According to Palatitz (2012) food accessibility is influenced even by the height of the vegetation. Permanent crops with the character of grassy and herbaceous societies, such as alfalfa, permanent grasslands, fallows, not requiring any intensive use of pesticides and with lower height, may be considered positive from the viewpoint of the food supply.

Crops are characterized by different growth phases. Crops can have different impacts on the food supply in different growth phases. In the period of feeding fledglings in the nest, maize and sunflower for example (negative crops according to Palatitz (2012)) create dense and high vegetation which is not suitable in terms of food accessibility. Phases of growth and crop cultivation were compared to the period and phases of the oc- 


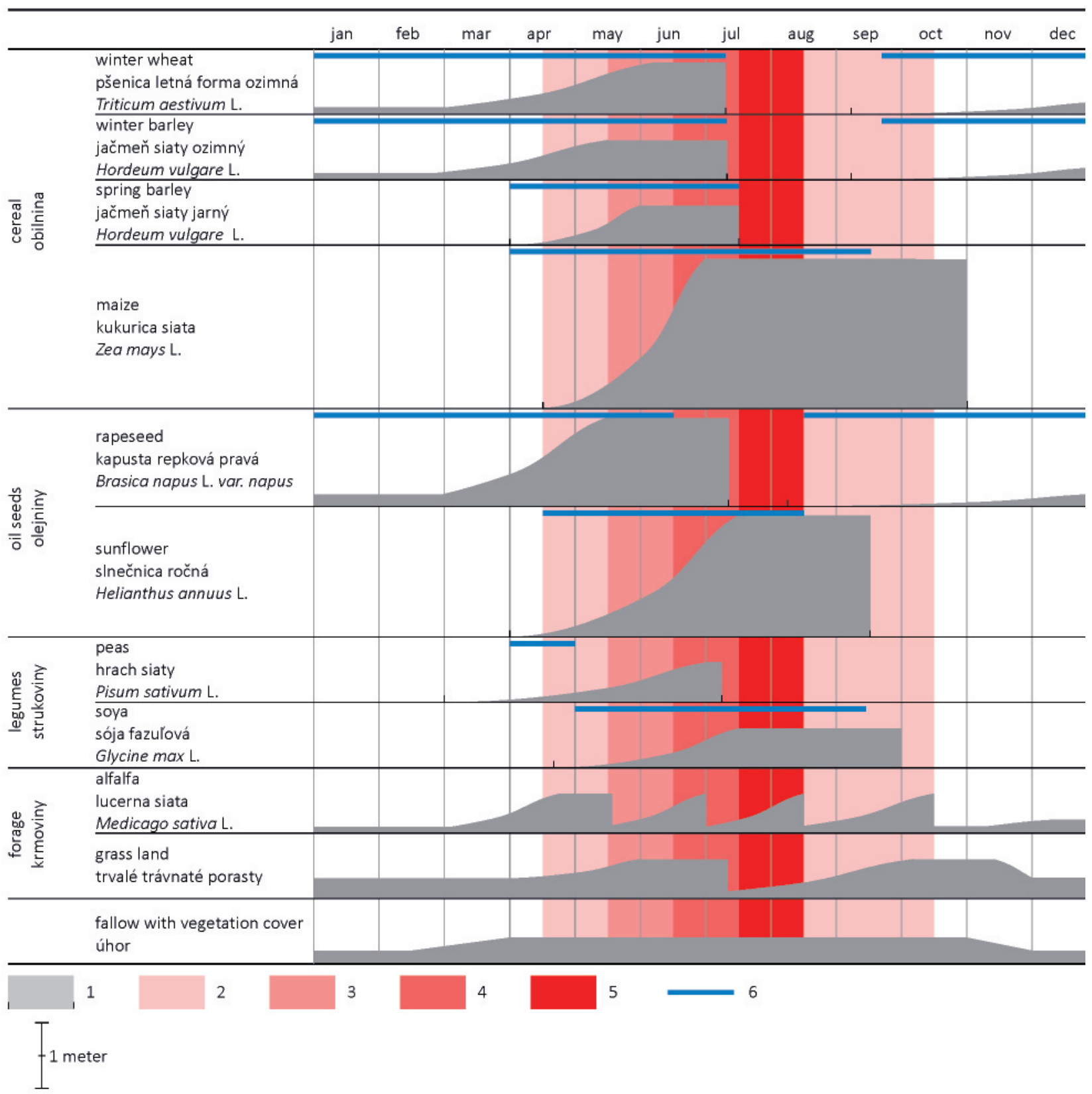

Fig. 1. Growth of crops during the year and the presence of Falco vespertinus at the nesting site. Legend: 1 - agricultural crops; $2-$ occurrence at nesting site; 3 - incubation of clutch; 4 - hatching; 5 - feeding fledglings on the nest; 6 - period of application of insecticides.

Obr. 1. Vývin porastu pol’nohospodárskych plodín v priebehu roka a prítomnost' Falco vespertinus na hniezdisku. Legenda: 1 pol'nohospodárska plodina; 2 - obdobie výskytu sokola kobcovitého na Slovensku; 3 - inkubácia znášky; 4 - liahnutie; 5 - kŕmenie mlád'at na hniezde; 6 - obdobie aplikácie insekticídov.

currence of $F$. vespertinus in the study area (Fig. 1). As far as the crops, such as maize, sunflower and soya, are concerned, there was an overlap (limited) of the periods of increased food demand (period of feeding fledglings in the nest) and food accessibility (influenced by the presence of a crop with low food supply) (Fig. 1). 
When assessing the suitability of crops in terms of availability of food for $F$. vespertinus, we applied the method of creating four groups of crops according to Palatitz et al. (2011). Palatitz et al. (2011) crop categorization was based on observations of the behavior of $F$. vespertinus, which prefers agrocenoses with prevalence of grass-herbaceous vegetation and the appearence of insects. They created a categorization of individual crops in habitats in terms of food availability. In this sense we assigned values to the crops from 1 (negative) to 4 (very positive). The following were classified as negative crops (value 1): maize (Zea mays L.), sunflower (Helianthus annuus L.) and soya (Glycine max (L) Merr.). The neutral crop (value 2) was rapeseed (Brasica napus L. var. napus). The group of positive crops (value 3) was represented by winter wheat (Triticum aestivum L.), winter barley (Hordeum vulgare subsp. vulgare var. hybernum) and spring barley (Hordeum sativum L.). As these crops have similar agrotechnical farming requirements they were added to the evaluation classified as thickly-sown cereals. The group of very positive crops (value 4) was made up of lucerne crops, grass lands, and arable lands right after harvesting of the main crop in a certain time period and left fallow. Three more categories of the soil complex were further created from the point of view of the food supply accessibility. They were formed by reclassification of the sum of values given to individual crops in the crop rotation. They reflect the several years lasting presence of a crop in the crop rotation. In this way we identified the areas in which there were negative, neutral or positive crops represented on a long-term basis.

Another criterion was the assessment of (non-)observance of the principles of incorporation of crops in the crop rotation. Non-observation of crop rotation meant rotation which did not apply the principles of proper agro-technical crop cultivation, for example maize growing for more than four years at the same field, or soybean cultivation after sunflower. This may cause a surfeit of pests and subsequent application of greater amounts of pesticides. This was assigned the value 1 . Observed crop rotation was assigned the value 2. Crop diversity in the crop rotations was entered in the evaluation too. Assigning the value depended on the number of crops represented in the individual years during the study period and it ranged from 2 to 6 . By the subsequent synthesis of the assessed criteria we identified the areas in which adjusting the agrotechnical procedures was recommended so that the habitat conditions of $F$. vespertinus improved.

\section{Results}

L a n d s c a p e u s e

The evaluation comprised four groups of landscape use elements in the years 1949 and 2017 (Fig. 1, Tab. 1). In 2017 arable land prevailed. This represented the areas used for agricultural activities focusing on agricultural crop farming. An area left fallow was also part of this group. Non-forest woody and shrubby vegetation represented mainly the accompanying vegetation of roads. The species composition was made up of black locust (Robinia pseudoacacia), ailanthus (Ailanthus altissima), field maple (Acer campestre), European wild pear (Pyrus pyraster), black elder (Sambucus nigra) and poplar (Populus spp.). The species composition was affected by the natural seeding of invasive alien plant species. There we could observe these species in the initial stages of succession. Grass and herbaceous vegetation represented the accompanying vegetation near roads. There were also areas which could not be cultivated using agricultural machinery, and had thus become overgrown with ruderal vegetation. Their maintenance was included in the management measures of the Special Protection Area, which provided for their mowing at least once a year. The group of road networks and other built-up areas comprised made and unmade field paths providing access to the individual land units for the purpose of performing agricultural activities. The agricultural buildings were classified as built-up areas. In 2017 the landscape structure was almost identical to the

Tab. 1. Representation of landscape elements in the Sysl'ovské polia Special Protection Area in 1949 and 2017.

Tab. 1. Zastúpenie krajinných prvkov v Chránenom vtáčom území Sysl'ovské polia v roku 1949 a 2017.

\begin{tabular}{|c|c|c|c|c|c|c|c|c|c|c|}
\hline \multirow[t]{2}{*}{$\begin{array}{l}\text { year / } \\
\text { rok }\end{array}$} & \multicolumn{2}{|c|}{$\begin{array}{l}\text { non-forest } \\
\text { woody vegetation / } \\
\text { nelesná drevinová } \\
\text { a krovinová vegetácia }\end{array}$} & \multicolumn{2}{|c|}{$\begin{array}{l}\text { grass and herb- } \\
\text { aceous vegetation / } \\
\text { trávnato- } \\
\text { bylinné porasty }\end{array}$} & \multicolumn{2}{|c|}{$\begin{array}{l}\text { arable land / } \\
\text { orná pôda }\end{array}$} & \multicolumn{2}{|c|}{$\begin{array}{l}\text { road networks and } \\
\text { other built-up areas / } \\
\text { cestná siet' a ostatné } \\
\text { zastavané plochy }\end{array}$} & \multicolumn{2}{|l|}{$\sum$} \\
\hline & ha & $\%$ & ha & $\%$ & ha & $\%$ & ha & $\%$ & ha & $\%$ \\
\hline 1949 & 15.27 & 0.86 & 49.83 & 2.81 & 1692.42 & 95.46 & 15.42 & 0.87 & 1772.94 & 100.00 \\
\hline 2017 & 16.28 & 0.92 & 15.56 & 0.88 & 1729.26 & 97.54 & 11.84 & 0.67 & 1772.94 & 100.00 \\
\hline
\end{tabular}




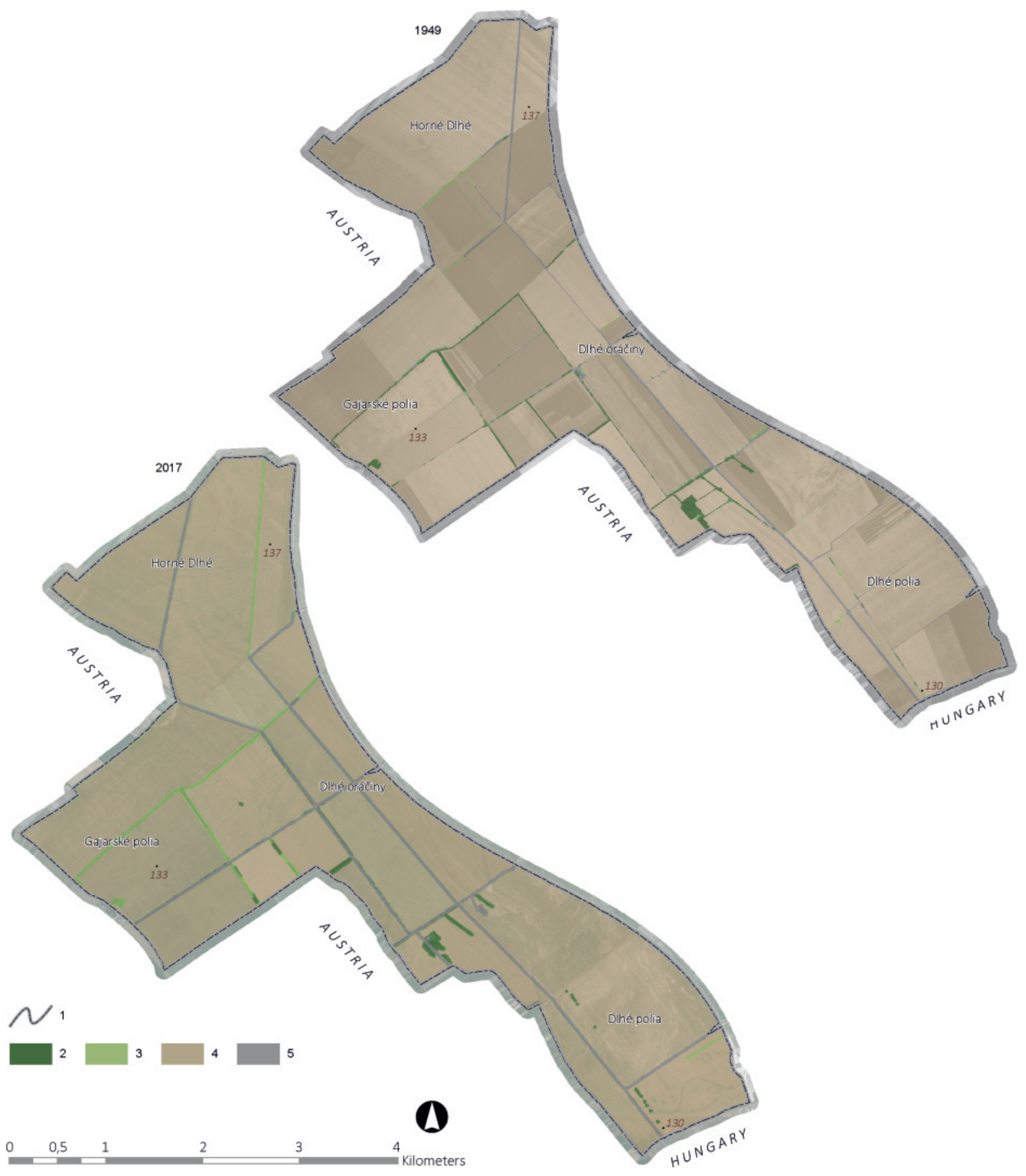

Fig. 2. Land use in the Sysl'ovské polia Special Protection Area in 1949 and 2017. Legend: 1 - border of Sysl'ovské polia Special Protection Area; 2 - non-forest woody vegetation; 3 - grass and herbaceous vegetation; 4 - arable land; 5 - road networks and other built-up areas.

Obr. 2. Využívanie krajiny v Chránenom vtáčom území Sysl'ovské polia v roku 1949 a 2017. Legenda: 1 - hranica Chráneného vtáčieho územia Sysl'ovské polia; 2 - nelesná drevinová a krovinová vegetácia; 3 - trávnato-bylinné porasty; 4 - orná pôda; 5 cestná siet' a ostatné zastavané plochy. 
structure in 1949. The same groups of landscape elements were identified. Subtle changes were found in the spatial representation (Fig. 2, Tab.1).

On the basis of the landscape structure analysis we may state that in the course of almost 70 years there were no significant changes in the landscape use. From that it is evident that agriculture is a long-term dominant activity and with regard to the usual agrotechnical procedures the changes may show themselves rather in the soil as such.

The low diversity of landscape elements with the prevalence of intensely-used arable land may not affect the occurrence of $F$. vespertinus. In the homogeneous landscape structure, the value/importance (for the occurrence of $F$. vespertinus) of micropatches grows significantly. Micropatches are part of the landscape structure (e.g. arboreal, shrub or grass hedgerows, the edges of field roads, ruderal communities). These fulfill the function of places of refuge for animals important as sources of food for $F$. vespertinus.

The landscape patch analysis on the basis of structure and diversity is presented in Tab. 2. From the table it follows that in the course of the period from 1949 to 2017 the overall length of the borderlines of patches (TE) significantly dropped by almost $100 \mathrm{~km}$ (Tab. 2). This is linked to the gradual increasing of the size of the individual land units and to the decreasing of the number of areas under cultivation, which also manifested itself in the patch density (PD) where we recorded a drop of $51.29 \%$. This decrease also showed itself in the edge density parameter (ED) representing the ratio of the patch perimeter with respect to the area. In this case we recorded a drop of $40.59 \%$, which indicates a possible decrease in the overall landscape diversity. The change in landscape patch diversity was observed by means of Shannon's and Simpson's Diversity Indices. In comparison with 1949 we recorded a landscape diversity decrease in 2017. Shannon's and Simpson's Evenness Indices were used to assess evenness. The values of these indices in 2017 dropped too. The values which we obtained using the Fragstats software also point to a decrease in patch diversity some changes in the landscape patches' structure. From the evaluation of the structure and diversity of the landscape patches it follows that by intensification of the areas under cultivation (combining and creating large land units), the impact of the edge effects was decreased at the same time. That means that the number, width and length of the edges in the landscape decreased and thus several unmade field paths and edge areas in the form of baulks, solitaires or avenues disappeared as well. The preservation of these species habitats may be crucial since they are an important part of the $F$. vespertinus diet. The stated findings may be useful as part of the planning tools in the management of the agricultural landscape of the Sysl'ovské polia Special Protection Area.

\section{Suitability of crop cultiva- t i o $\mathrm{n}$ o n a r a ble 1 a $\mathrm{nd}$}

In the period from 2004 until 2017, there were 9 agricultural crops incorporated in the crop rotation in which maize and thickly-sown cereals prevailed (Appendix 1).

Assessment of suitability of crop cultivation was done on the basis of the representation of negative/neutral/positive areas in the study area from the viewpoint of accessibility of the food supply for $F$. vespertinus. Negative areas, in which mainly maize, sunflower and soya are incorporated in the crop rotations, are represented the most. They take up $45.38 \%$ of the total extent of the arable land. They are located in the western part of the study area. Neutral areas are situated mostly in the eastern part and they take up $40.98 \%$. Positive areas with their $13.64 \%$ were represented the least. In these areas there are the crops which are considered positive (thickly-sown cereals, peas) or very positive (alfalfa and lucerne types) from the viewpoint of the food demands of $F$. vespertinus. Besides the fact that here are the most fertile soils, the area is also flat and easily accessible. Identified areas classified as negative have the highest production potential and at the

Tab. 2. Structure and diversity indices of landscape patches in the Sysl'ovské polia Special Protection Area in 1949 and 2017. Tab. 2. Ukazovatele štruktúry a diverzity plôšok krajiny Chráneného vtáčieho územia Sysl'ovské polia v rokoch 1949 a 2017.

\begin{tabular}{|c|c|c|c|c|c|c|c|c|}
\hline year / & $\begin{array}{l}\text { total } \\
\text { area / } \\
\text { celková } \\
\text { rozloha }\end{array}$ & $\begin{array}{l}\text { total } \\
\text { edge / } \\
\text { dížka } \\
\text { hraníc }\end{array}$ & $\begin{array}{l}\text { edge } \\
\text { density / } \\
\text { hustota } \\
\text { hraníc }\end{array}$ & $\begin{array}{l}\text { patch } \\
\text { density / } \\
\text { hustota } \\
\text { plôšok }\end{array}$ & $\begin{array}{l}\text { Shannon's } \\
\text { diversity index / } \\
\text { Shannonov } \\
\text { index diverzity }\end{array}$ & $\begin{array}{l}\text { Simpson's } \\
\text { diversity index / } \\
\text { Simpsonov } \\
\text { index diverzity }\end{array}$ & $\begin{array}{l}\text { Shannon's } \\
\text { evenness index / } \\
\text { Shannonov index } \\
\text { vyrovnanosti }\end{array}$ & $\begin{array}{l}\text { Simpson's } \\
\text { evenness index / } \\
\text { Simpsonov index } \\
\text { vyrovnanosti }\end{array}$ \\
\hline & (ha) & (m) & (m/ha) & (n/100 ha) & & & & \\
\hline 1949 & 1772.94 & 243,451 & 137.09 & 115.83 & 0.2267 & 0.0877 & 0.1635 & 0.1169 \\
\hline 2017 & 1772.94 & 144,642 & 81.45 & 56.42 & 0.1422 & 0.0484 & 0.1026 & 0.0645 \\
\hline
\end{tabular}


same time they belong among the most significant land units from the viewpoint of their size. Their potential is used for cultivation of crops which are considered favourable from the economic point of view. By contrast, considering its character, they may have a negative impact on the accessibility of the food supply for $F$. vespertinus.

In our evaluation of the (non)observance of crop rotation principles we found that in the period from 2004 until 2017 these principles were observed in $75.73 \%$ of the area and not observed in $24.27 \%$ of the area of arable land. On the basis of the principles of growing technologies of individual crops we may consider this as positive for $F$. vespertinus. This condition was found in the western part of the study area, and in the southern part too in the form of small fragmented areas. This criterion does not influence the landscape suitability directly, but it increases the potential for positive or negative impact on the food supply accessibility.

Crop diversity in the crop rotation was evaluated on the basis of the number of crops represented in the rotation system in the study area during the 14-year period in all the identified land units. The areas in which two to six crops rotated were singled out. The areas with three crops were represented the most $(54.15 \%)$, the areas with six crops the least $(0.27 \%)$. Then we identified the areas with two crops $(2.15 \%)$, four crops $(38.34 \%)$ and five crops $(5.09 \%)$. There were no land units with one, seven, eight or nine crops. The areas in which they cultivated two or three crops during the study period were considered negative from the viewpoint of the crop diversity in the further analyses. By contrast, the areas with five or six crops were considered positive. Neutral areas were those with four crops incorporated in the crop rotation. The negative areas represented in 56.30\% of the arable land, while the positive ones made up only $5.36 \%$ of the arable land.

Most of the area is represented by fields with low crop diversity in agro-technical crop rotation. This lack of diversity may be reflected in the range of food available for $F$. vespertinus.

The next step was determination of arable land use suitability in the studied area (within individual fields). This suitability was evaluated using a combination of the above criteria and is expressed as their synthesis (Fig. 3).

The areas with negative assessment in all the criteria take up 319.79 ha (18.48\%) from the total area of arable land. Three land units in the western part of the area fall into this group, while from the viewpoint of size two of them (in the Gajarské polia) are the biggest (169.93 ha and $115.03 \mathrm{ha}$ ).

\section{Discussion}

In this paper we have evaluated the land use and determined the potential suitability of agricultural landscape for $F$. vespertinus. At higher population densities it occurs in Hungary, where its habitat is the Pannonian steppe. This represents the western part of its expansion. In the conditions of Slovakia $F$. vespertinus prefers agrocenoses, so-called cultural steppe.

Evaluation of landscape use and its suitability for $F$. vespertinus was carried out at two levels. They were evaluated on the basis of the landscape elements represented, especially patches which may function as places of refuge, the presence of which may provide suitable habitat conditions for $F$. vespertinus. The study area is characterized by homogeneous, scarcely changing landscape structure, the proof of which is the almost unchanging representation of individual landscape elements in the period between 1949 and 2017. The occurrence and abundance of $F$. vespertinus may be significantly influenced by the presence of refuge places in the form of avenues, windbreaks, grass and herbaceous vegetation, and shrubs that have the potential to provide for its habitat requirements. The presence of such elements was greater in the past. Intensive farming has gradually decreased their representation, which might have led to the decreasing incidence of red-footed falcons in Slovakia (Slobodník et al. 2017). The species' presence in the area may also be influenced by other ways of using agricultural land near the border with Austria (crop rotation variety, small scale farming and greater diversity of cultivated crops).

The determination of landscape suitability was based on our criteria. The individual criteria do not have the same meaning/value in terms of satisfying the habitat claims of $F$. vespertinus. On the basis of the importance of individual criteria the sequence of the criteria was set as follows: 1) representation of positive/negative agricultural crops with respect to the food supply accessibility, 2) diversity of crops incorporated in the crop rotation, 3) (non-)observance of crop rotation principles in the study period. The most important in terms of habitat requirements is the presence of positive/negative crops. With respect to the habitat demands, the (non)observance of crop rotation is the least important. The crop rotation mirrors the principles of individual 


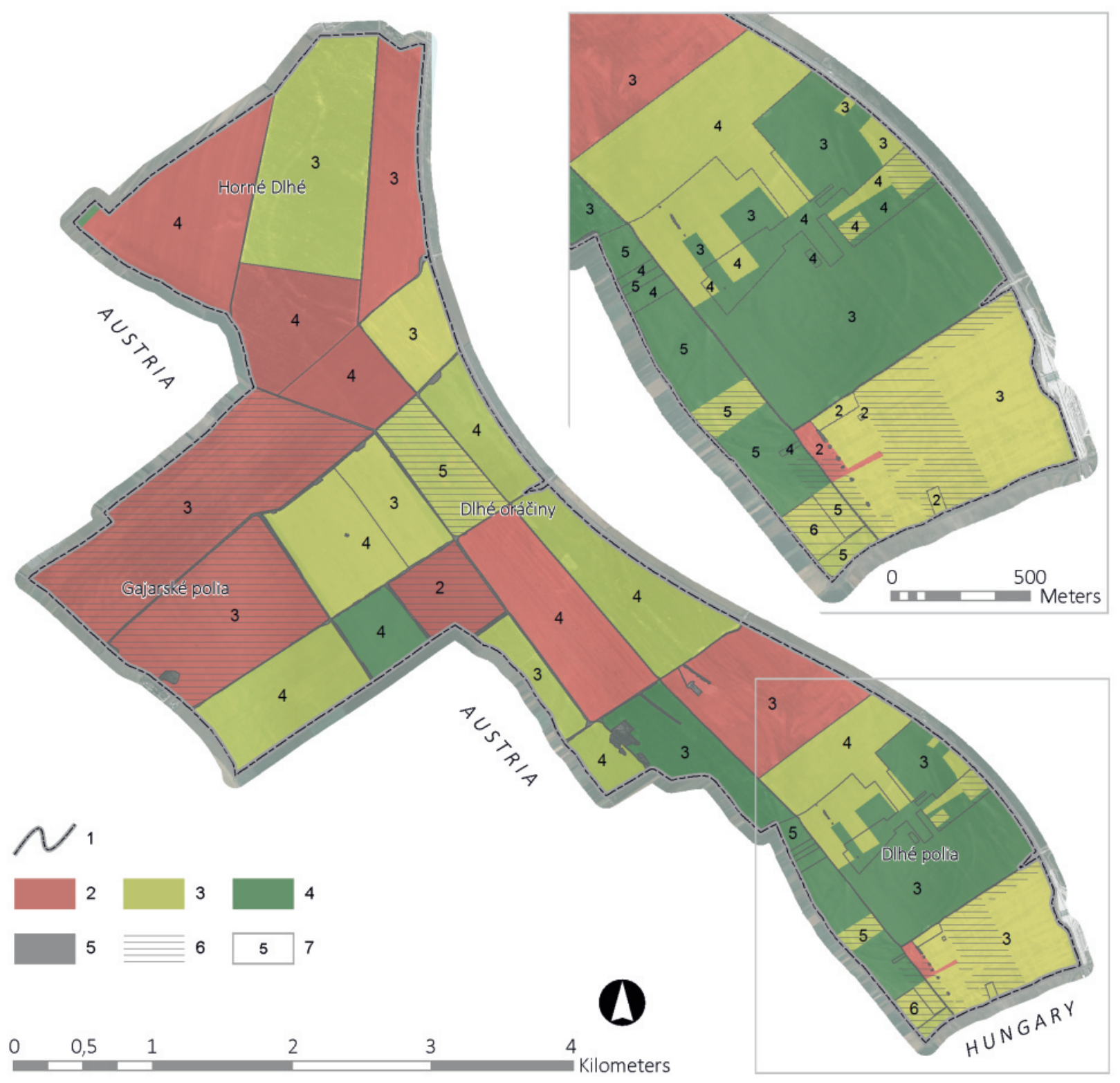

Fig. 3. Agricultural land-use suitability in the Sysl'ovské polia Special Protection Area in 2004-2017. Legend: 1 - borderline of the Sysl'ovské polia Special Protection Area; 2 - areas with prevalence of negative crops in the crop rotation; 3 - areas with prevalence of neutral crops in the crop rotation; 4 - areas with prevalence of positive crops in the crop rotation; 5 - areas not used for agriculture; 6 - areas with no crop rotation; 7 - number of crops in the crop rotation.

Obr. 3. Vhodnost' využívania pol'nohospodárskej pôdy v Chránenom vtáčom území Sysl'ovské polia v rokoch 2004 - 2017. Legenda: 1 - hranica Chráneného vtáčieho územia Sysl'ovské polia; 2 - plochy s prevahou negatívnych plodín v osevnom postupe; 3 - plochy s prevahou neutrálnych plodín $v$ osevnom postupe; 4 - plochy s prevahou pozitívnych plodín $v$ osevnom postupe; 5 - pol'nohospodársky nevyužívané plochy; 6 - plochy s nedodržaným osevným postupom; 7 - počet plodín v osevnom postupe. 
agricultural crop cultivation, which does not necessarily have an impact on the food supply accessibility, if there are positive and neutral crops in it. The problem may lie in the use of pesticides, the intensity of which is increased with cultivation of one crop in the same area for a couple of successive years. Based on the habitat demands of $F$. vespertinus we can recognize fields in the study area which are characterized by the observation of crop rotation. They meet the $2^{\text {nd }}$ and $3^{\text {rd }}$ established criteria, but do not meet the first and most important criterion. The stated soil complexes are situated in the northern and central parts of the study area. They make up 463.76 ha $(26.79 \%)$ of the total area of arable land. The soil complexes included in the stated group make up in total $44.19 \%$ of the overall extent of the protected area, and they require attention with respect to its further use, focusing on creation of such conditions which improve the accessibility of the food supply for $F$. vespertinus. The soil complexes which with respect to the assessed criteria were evaluated as positive are located mostly in the south-eastern part of the area. In this area there was greater diversity of agricultural crops and in the crop rotations it was the crops suitable from the viewpoint of accessibility of the food supply for $F$. vespertinus which prevailed.

On the basis of the evaluation of arable land use suitability we may state that the monoculture representation of agricultural crops (e.g. maize) does not necessarily provide enough food opportunities for $F$. vespertinus. The crop rotation itself in the whole area, in which only a couple of crops altered in the course of 14 years, may be considered less positive. The crop which significantly prevailed was maize, which was grown in some land units for 2-3 years in a row, and from the agronomical point of view, as stated by Holúbek (2007), the less positive assessment is correct. Molnárová (2016) states that if maize is grown for 2-3 years in a row, the occurrence of diseases and pests increases, and consequently also the use of pesticides, which may have an effect on other insect species as well. But there were also land units in which maize was grown for 6 years in a row. That is not suitable either from the agronomical point of view or from the viewpoint of the falcons' food supply accessibility. With sunflower or rapeseed it is similar. Inaccurate observance of crop rotation showed itself in the sequence of the individual crops. Besides the fact that maize, sunflower and soya belong in the group of negative crops, in the crop rotation they were arranged one after anoth- er. According to the results of Ernst et al. (2016) and Kovár et al. (2016) the crop rotation in which sunflower or maize follows soya, cannot be considered suitable for $F$. vespertinus. The correct crop rotation ensuring the improvement of soil properties and biodiversity preservation presumes incorporation of these crops in the rotation so that the direct pre-crop is a cereal, in the best case winter wheat. By observing the principles of crop growing it is possible to eliminate the use of pesticides and thus to increase the diversity of various insect species. Taken as a whole, the observance of the principles of growing individual agricultural crops, mainly from the agronomical point of view, may be evaluated as positive. Since we are dealing with a Special Protection Area, in suggestions for providing optimal conditions for the occurrence of $F$. vespertinus it is necessary to find a compromise between the principles and rules of agricultural crop growing and the principles of farming activities on arable land in the protected areas which are recommended by Decree No. 234/2006 Special Management Plan for the Sysl'ovské polia SPA 2010-2019 (Chavko \& Maderič 2009) and the proposal of a programme for saving the red-footed falcon for the period from 2017 until 2021 (Slobodník et al. 2017). This will lead to the formation of a landscape which may ensure favourable habitats for $F$. vespertinus without significant economic effect on agricultural business. Recommendations for the creation of optimal conditions proceed from the assessments and it follows from them that it is necessary to provide higher diversity of agricultural crops in the crop rotation, mostly by using positive or neutral crops (apart from the stated ones also beans or common sainfoin). In this way the condition of the vegetation will improve, which may lead to elimination of pesticide use and subsequent increase in species diversity and insect abundance. This does not mean the complete elimination of negative crops from the crop rotation, since they have good marketing opportunities and are rather stable on the market. In the whole study area we would recommend increasing the share of ecostabilizing landscape elements and ensuring the presence of permanent grass vegetation. In addition to increasing the landscape diversity, an optimal "soil chemistry" for future crops would be ensured, and so would the keeping of the principles of $7 \%$ greening of the soil which proceeds from SR Government Regulation No. 342/2014 Coll. Grass vegetation should be located in the areas identified as negative in our evaluation of all the criteria. Since in two cases we deal with large 
land units with areas of more than $100 \mathrm{ha}$, it is possible to divide them temporarily with zones of multifunctional grass cover, whose width will correspond to the needs of the agricultural machinery. Effective mowing will be ensured, the date of which depends on the habitat demands of the criterion species. These zones should be seeded with multi-species flowering meadow plants mixture. In the other negatively assessed areas (the ones that do not meet the criterion of positive/negative crop representation) it would be appropriate to incorporate in the crop rotation those kinds of crops which meet the requirements for the species' food supply. Another alternative for increasing the landscape diversity and biodiversity could be the soil protection function in certain methods of soil tillage, e.g. strip tilling. This has positive impact on the soil because the volume of organic matter in the soil increases, it regulates the content of nitrogen and phosphorous, and agrotechnical procedures are handled more easily. It eliminates chemicalisation and increases biodiversity. The stated recommendations represent only a part of many agrotechnical possibilities of "friendly" management of agricultural land which lead to observance of the principles of the common agricultural policy in the interests of providing better landscape management.

\section{References}

Bengtssona J, Nilssonb SG, Francc A, Menozzid P 2000: Biodiversity, disturbances, ecosystem function and management of European forests. Forest Ecology and Management 132: 39-50.

Chamberlain DE, Fuller RJ, Bunce RGH, Duckworth JC \& Shrubb M 2000: Changes in the abundance of farmland birds in relation to the timing of agricultural intensification in England and Wales. Journal of Applied Ecology 37: 771-788.

Chavko J \& Maderič B 2009: Program starostlivosti Chráneného vtáčieho územia Sysl'ovské polia 2010 - 2019 [Management plan of Special Protection Area Sysl'ovské polia 2010-2019] Raptor Protection of Slovakia, Bird Life Slovakia, State Nature Conservancy of the Slovak Republic, Banská Bystrica, 67.

Cushman SA, McGarigal K \& Neel MC 2008: Parsimony in landscape metrics: strength, universality, and consistency. Ecological Indicators 8(5): 691-703.

Černý I \& Candráková E 2015: Rastlinná výroba [Plant production]. Slovak University of Agriculture, Nitra,

\section{9. [In Slovak]}

Decree No. 234/2006 Coll. which declares the Special Protection Area Sysl'ovské polia

Donald PF, Green RE \& Heath MF 2001: Agricultural intensification and the collapse of Europe's farmland bird populations. Proceedings of the Royal Society of London B 268(1462): 25-29. DOI: 10.1098 /rspb.2000.1325

Donald PF, Sanderson FJ, Burfield IJ \& van Bommel FPJ 2006: Further evidence of continent-wide impacts of agricultural intensification on European farmland birds, 1990-2000. Agriculture, Ecosystems and Environment 116: 189-196.

Ernst D, Kovár M \& Černý I 2016. Effect of two different plant growth regulators on production traits of sunflower. Journal of Central European Agriculture 17(4): 998-1012. DOI: dx.doi.org/10.5513/ JCEA01/17.4.1804.

FAOSTAT 2007: FAO Statistical database. Food and agricultural organization, Rome, Italy, PAGES???

Fehérvári P, Solt S, Palatitz P, Barna K, Ágoston A, Gergely J \& Harnos A 2012: Allocating active conservation measures using species distribution models: a case study of red-footed falcon breeding site management in the Carpathian Basin. Animal Conservation 15(6): 648-657. DOI: 10.1111/j.14691795.2012.00559.x

Flohre A, Fischer C, Aavik T, Bengtsson J, Berendse F, Bommarco R, Ceryngier P, Clement LW, Dennis C, Eggers S, Emmerson M, Geiger F, Guerrero I, Hawro V, Inchausti P, Liira J, Morales MB, Oñate JJ, Pärt $\mathrm{T}$, Weisser WW, Winqvist $\mathrm{C}$, Thies $\mathrm{C}$ \& Tscharntke T 2011: Agricultural intensification and biodiversity partitioning in European landscapes comparing plants, carabids and birds. Ecological Applications 21(5): 1772-1781.

Forman RTT \& Godron M 1993: Krajinná ekologie [Landscape ecology]. Academia, Praha, 583.

Forman RTT 1995: Land mosaics: The ecology of landscape and regions. Cambridge University Press, New York, 632.

Fülöp Z \& Szlivka L 1988: Contribution to the food biology of the red-footed falcon (Falco vespertinus). Aquila 25(1): 174-181.

Godfray HCJ, Beddington JR, Crute IR, Haddad L, Lawrence D, Muir JF, Pretty J, Robinson S, Thomas SM \& Toulmin C 2010: Food security: the challenge of feeding 9 billion people. Science 327(5967): 812-818. 
Government Regulation No. 342/2014 Coll. which lays down the rules for granting support in agriculture in relation to the schemes of decoupled direct payments as amended by No. 76/2015 Coll., 10/2016 Coll., 47/2017 Coll.

Haraszthy L, Rékási J \& Bagyura J 1994: Food of the red-footed falcon in the breeding period. Aquila 101: 93-110.

Hill MO 1973: Diversity and evenness: a unifying notation and its consequences. Ecology 54(2): 427-432.

Holúbek R, Jančovič J, Gregorová H, Novák J, Ďurková E \& Vozár L 2007: Krmovinársto - manažment pestovania a využívania krmovín [Fodder growing Management of Cultivation and Use of Fodder Crops]. Slovak University of Agriculture in Nitra, Nitra, 419. [In Slovak]

Kalivoda H, Petrovič F, Kalivodová E \& Kürthy A 2010: Influence of the landscape structure on the butterfly (Lepidoptera, Hesperioidea and Papilionoidea) and bird (Aves) taxocoenoses in Vel'ké Leváre (SW Slovakia). Ekológia 29(4): 337-359. DOI:10.4149/ekol 201004337.

Keve A \& Szijj J 1957: Distribution, biologie et alimentation du faucon kobez Falco vespertinus L. en Hongrie. Alauda 25(1): 1-23.

Kovár M, Černý I \& Ernst D 2016: Analysis of relations between crop temperature indices and yield of different sunflower hybrids foliar treated by biopreparations. agriculture 62(1): 28-40. DOI: 10.1515/agri-2016-0004.

Krebs JR, Wilson JD, Bradbury RB \& Siriwardena GM 1999: The second silent spring? Nature 400: 611-612. DOI: $10.1038 / 23127$

McGarigal K \& Marks B 1995: FRAGSTATS: Spatial analysis program for quantifying landscape structure. Retrieved November 6, 2017, from https://andrewsforest.oregonstate.edu/sites/default/files/lter/p ubs/pdf/pub1538.pdf

McGarigal K, Cushman SA \& Ene E 2012: FRAGSTATS v4. Spatial Pattern Analysis Program for Categorical and Continuous Maps. University of Massachusetts. Amherst. Retrieved September 14, 2017, from http://www.umass.edu/landeco/research/fragstats/fragstats.html.

Molnárová J \& Žembery J 2016: Rastlinná výroba I. Obilniny, strukoviny, olejniny [Plant production I. Cereal, legumes, oil seeds]. Slovak University of Agriculture, Nitra, 188. [In Slovak]

Palatitz P, Fehérvári P, Solt S, Kotymán L, Neidlert D \& Harnos A 2011: Exploratory analyses of foraging habitat selection of the red-footed falcon (Falco vespertinus). Acta Zoologica Academiae Scientiarum Hungaricae 57(3): 255-268.

Palatitz P 2012: Establishing the scientific background of red-footed falcon (Falco vespertinus) conservation management. (Doctoral dissertation). Doctoral School of Animal Science, Gödöllö, 20.

Palatitz P, Solt S, Horváth E \& Kotymán L 2015: Hunting efficiency of fed-footed falcons in different habitats. Ornis Hungarica 23(1): 32-47. DOI: https://doi.org/10.1515/orhu-2015-0003.

Purger JJ 1996: Numbers and distribution of red-footed falcon (Falco vespertinus) nests in Voivodina (Northern Serbia). Journal of Raptor Research 30(3): 165-168.

Purger JJ 1997: Accidental death of adult red-footed falcons Falco vespertinus and its effect on breeding success. Vogelwelt 118: 325-327.

Robinson RA \& Sutherland WJ 2002: Post-war changes in arable farming and biodiversity in Great Britain. Journal of Applied Ecology 39(1): 157-176. DOI: 10.1046/j.1365-2664.2002.00695.x

Ružička M \& Ružičková H 1973: Druhotná štruktúra krajiny ako kritérium biologickej rovnováhy [Secondary structure of landscape as a criterion of biological balance]. Quaestiones geobiologicae/Problémy biológie krajiny 12(1): 23-62. [In Slovak with English summary]

Slobodník R, Chavko J, Lešová A, Guziová Z \& Maderič B 2017: Program záchrany sokola červenonohého (Falco vespertinus, Linnaeus 1766) na obdobie 2017 - 2021 [Programme for saving the red-footed falcon (Falco vespertinus, Linnaeus 1766) for the period from 2017 until 2021]. State Nature Conservancy of the Slovak Republic \& Raptor Protection of Slovakia, Banská Bystrica \& Bratislava, 34. [In Slovak]

Turner MG 1990: Spatial and temporal analysis of landscape patterns. Landscape Ecology 4(1): 21-30.

UN DESA 2011: World population prospects. The 2010 revision. Volume I: Comprehensive tables. United Nations, New York, 481. Retrieved September 14, 2017, from http://www.un.org/en/development/ $\mathrm{desa} /$ population/publications/pdf/trends/WPP2010/WPP2010_Volume-I_ComprehensiveTables.pdf 




